\title{
EFFECT OF GUAVA LEAVES ( Psidium Guajava L.) AS A SOURCE OF ANTIOXIDANTS ON HEPATOTOXIC RATS Afaf H. B. Amer ${ }^{*}$ \\ Food Science Dept., Faculty of Family Sciences, Taibah University, KSA.
}

\begin{abstract}
The present work was designed to identify the total flavonoids content and the individual fractions. Also, to investigate the effect of different levels of Psidium Guajava L., leaves (P.G.L., L.) on daily food intake, body weight gain and liver weight to body weight ratio in hepatotoxic rats. Serum lipid profile and liver function were also studied. Thirty male albino rats (Sprago Dawley Strain) were divided into two main groups. The first main group $(n=6)$ was fed on basal diet (B.D.) and used as a control negative group. The second main group (24 rats) was subcutaneous injected with $\mathrm{CCL}_{4}$ in Paraffin oil (50\% v/v $2 \mathrm{ml} / \mathrm{kg}$ bwt) twice a week for two weeks, to induce chronic damage in the liver. Then divided into four subgroups as the following: Group 1 received B.D. only as a positive control group. Groups 2, 3and 4 received B.D. containing different levels (3, 6 and 9\%) P.G.L., leaves, respectively. Hepatotoxic rats which fed on B.D. supplemented with (9\%) P.G.L.L. resulted the best improvement of nutritional value in addition to the percent of liver weight/body weight. The mean value of serum cholesterol, triglycerides, low density lipoprotein cholesterol (LDL-C), very low-density lipoprotein (VLDL-c), aspartate amino transferase (AST) and alanine amino transferase (ALT) decreased in groups treated with $(3 \%, 6 \%$ and $9 \%)$ P.G.L., $\mathrm{L}$. as compared to the positive control group, while high-density lipoprotein cholesterol (HDL-c) increased. The conclusion reached was that inclusion of P.G.L., $L$ in some stable food as bakery may help to improve liver function in hepatotoxic disease. The antioxidant power content of Psidium Guajava L., Leaves is the bases for contribution of these actions.
\end{abstract}

Keywords: Psidium Guajava L., Hepatotoxic, $\mathrm{CCL}_{4}$, flavonoids, cholesterol, triglycerides

\section{INTRODUCTION}

As the liver cleans all the blood, when a person takes in chemicals that can harm the body, the liver must take them out. One of the chief offenders to the body is medical drugs. All medical drugs that are put on the skin, inhaled, injected or swallowed find their way to the liver for processing. The most common liver pathway that breaks down drugs is P450 (Mumoli et al., 2006).

Liver toxicity is very common. Toxicity occurs when the liver becomes overloaded with toxins. These toxins can come from the diet, water, air, drugs, etc. It can also occur when drugs supplements interact with the P450 pathway has to kick them out they usually go into the liver for later processing, which can only occur when the P450 pathway isn't busy-this very rarely happens. When liver is toxic, it cannot process toxins as it used to (Nooman et al., 1997).

Liver toxicity is reversible in most cases once the offending substance is removed. The liver is the only known organ in the body that has the ability to regenerate itself to full function again so long as $25 \%$ of the liver remains (Ronda Beluke and Chom., 2007). 
Acute and chronic liver diseases constitute a global concern, and medical treatments for these diseases are often difficult to handles and have limited efficiency (Lee et al., 2007). Therefore, there has been considerable interest in the role of complementary and alternative medicine for the treatment of liver disease (Shen et al., 2009).

Fruits have significant higher quality of phenol antioxidants than vegetables. Chen and Yen, (2007) demonstrated that although the contents of total phenolic compounds and flavonoids in guava leaf extracts were lower than that of aqueous rosemary extract, guava leaf extracts showed the strongest antioxidant activity in most of tested methods. This fact suggests that guava leaf extract are a good source of water soluble natural antioxidants. It contains a mixture of phenolic compounds such as gallic, quercetin, procatechuic acid. Chlorogenic acid, caffic acid, kampferol and ferulic acid, it could be estimated that the phenolic compounds present in the guava leaves played an important role in antioxidant activity, directly through the mechanism of reduction of oxidized intermediates in the chain reaction (Oh et al., 2004).

Chuanoi et al., (2009) reported that the extract from Psidium guajava, L. leaves contain important phyto-constituents mainlyu phenolic, flavonoids, carotenoids, terpenoid and triterpene. The major component of the antioxidant system in mammalian cells consists of three enzymes, namely, superoxide dismutase (SOD), catalase (CAT) and glutathione peroxidase. These enzymes work in concert to detoxify superoxide anion and hydrogen peroxidase in cells. Therefore, reducing oxidative stress may be an effective therapeutic strategy for preventing and treating hepatic fibrosis (Amin and Ghoneim, 2009).

The aim of this work was to investigate the effect of guava leaves (Psidium guajava, L.), leaves on rats exposed to chronic liver toxicity by carbon tetrachloride.

\section{MATERIALS AND METHODS}

\section{Materials}

Guava leaves (Psidium Guajava, L.) were obtained from a farm in Saudi Arabia. The leaves were cleaned and washed under tap water, dried by solar energy and then crushed to a fine powder.

Chemicals: Casein, vitamins, minerals, cellulose and choline chloride were purchased from pharm and chem. Ind. Comp.

Corn oil and corn starch were obtained from local market. Kits used to determine serum biochemical parameters were supplied by Human, Germany.

\section{Chemical Analysis}

Moisture, protein, fat, ash, crud fiber, polyphenols content in (Psidium Guajava L.) leaves were determined according to the method outlined in A.O.A.C. (1995) (P.G.L.L.) flavonoids was determined in (P.G.L.L.) according to the method of Price et al., (1978). Phenolic compounds of (P.G.L.L.) samples were extracted according to the method outlined by Ben-Hammouda et al., (1995) and (Caporale et al., 1985). 
Experimental animals: Thirty male albino rats of Sprago Dawley strain weighing $220 \pm 10 \mathrm{~g}$ were obtained from the Laboratory of Animals Colony.

\section{Experimental Animals Design:}

Rats were housed in individual cages under hygienic laboratory conditions and were fed on basal diet adlibitum for one week for adaptation in the animal house.

The basal diet in the preliminary experiment consists of $14 \%$ casein (Protein $>85 \%$ ), corn oil $4 \%$, salt mixture $3.5 \%$, vitamins mixture $1 \%$, Choline chloride $0.25 \%$, cellulose $5 \%$, and (72.25\%) corn starch (Reeves et al., 1993).

The salt mixture and vitamin mixture were prepared according to (Hegsted et al., 1941 and Campbell, 1963). After a period of adaptation on basal diet, rats were divided into two main groups. The first main group (6 rats) fed on basal diet (negative control group). The second main group: Forty two rats were subcutaneously injected with $\mathrm{CCL}_{4}$ in paraffin oil $(50 \% \mathrm{v} / \mathrm{v}$ $2 \mathrm{ml} / \mathrm{kg}$ bwt.) twice a week for two weeks, to induce chronic damage in the liver. These rats were divided into four subgroups. One of them (6 rats) was fed on basal died used as a positive control group. The other subgroups ( 3 subgroups were fed on basal diet containing different levels from $(3,6$ and 9\%) (P.G.L.L.).

Body weight, food consumption were measured twice a week and total food intake of the experimental period (4 weeks) was calculated according to (Chapman et al., 1959).

\section{Biochemical Analysis of Serum:}

At the end of experiment the rats were starved for $12 \mathrm{hr}$., and then Sacrificed under anaesthetized. Blood samples were collected from hepatic portal vein by the means of fine capillary glass tube according to (Schermer, 1967).

Each blood sample was placed in a dry clean centrifuge tube, and then centrifuged for 10 minutes at 3000 round per minute to separate the serum. Serum was carefully separated into dry clean wasserman tubes by using a Pasteur pipette and kept frozen till analysis.

Total cholesterol was determined in serum according to the method described by (Allain et al., 1974).

Triglycerides were determined in the serum according to the method described by (Trinder and Ann., 1969).

Determination of serum HDL-C was according to the method described by Lopes Vitelia et al., (1977). Serum VLDL-c and Serum LDL-c were determined according to Friedwald et al., (1972), aspartate amino transferase (AST) and alanine amino transferase (ALT) (Ritman and Frankel, 1957).

Statistical analysis: Statistical analysis was carried out using SAS, (2004) Users Guide. The results were expressed as mean \pm SD. Data were analyzed by one way analysis of Variance (ANOVA). The differences between means were tested for significance using least significant difference (LSD) test at $\mathrm{P}<0.05$. 


\section{RESULTS AND DISCUSSION}

\section{Chemical Composition of Psidium Guajava L. Leaves:}

Major chemical of fresh P.G.L.L. are presented in table (1). Results revealed that, moisture, ash, protein, fiber, carbohydrate and fat of Psidium Guajava L., leaves were $(80,00,1.22,0.94,3.14,14.39$ and $0.32 \%)$ respectively.

Also the data in table (1) show the contents Psidium Guajava L., Leaves from ascorbic acid, calcium, phosphorus and iron (30.49, 34.50 and $1.10 \mathrm{mg}$ ) respectively. These results revealed that ascorbic acid content of P.G.L. Leaves was (247.01). P.G.L.L. is characterized by the high content of ascorbic acid, calcium, phosphorus and iron which is the main constituent of P.G.L. Leaves.

Determination of Polyphenols and Flavonoids Compounds of Dried Psidium Guajava L., Leaves

The results in table 2 and 3 shows that total polyphenols and flavonoids of dried P.G.L.L. Results revealed that it represented 576.11 and $35.00 \mathrm{mg} / 100 \mathrm{~g}$ dry matter. On the other hand, table (3) shows the identified phenolic compounds extracted from P.G.P.L.L. which fractionated using high performance liquid chromatography. In our study, we could identify seven phenolic compounds in P.G.L., Leaves. Because of the available standard phenolic compounds. The phenolic compounds identified in P.G.L., leaves were gallic acid, progallic, catechin, protochatchioc, furan, ferulic acid and quercetin are presented in leaves respectively.

In this respect Gutierrez et al., (2008) confirmed that Psidium Guajava as well as leaves contain important phyto-constituents mainly phenolic, flavonoid, carotenoids, terpenoid and triterpene. Dietary polyphenols represent a group of secondary metabolites which widely occur. They are mostly dereivatives, and or isomers of flavones, isoflavones, flavonols, catechins and phenolic acids. Dietary polyphenols exhibit many biologically significant functions, such as protection against oxidative stress and degenerative diseases. Experimental data indicate that most of these biological actions can be attributed to their intrinsic antioxidant capabilities (Han et al., 2007).

Biological Effect of (Psidium Guajava L.) Leaves on Daily Food Intake, Body Weight Gain \% and Liver weight/body weight \% in Hepatotoxic Rats:

The effect of P.G.L. Leaves on the daily food intake (F.I.), body weight gain $\%$ (B.W.G.\%) and liver weight/body weight in non-hepatotoxic and hepatotoxic rats. Results are presented in table (4). As shown that the mean value \pm of daily F.I. (g/day) for negative control (non-hepatotoxic rats) fed on B.D. only, hepatotoxic group fed on B.D. plus $3 \%, 6 \%$ or $9 \%$ P.G.L.L. were increase in daily food intake as compared to rats in control positive group (hepatotoxic rats) which fed the B.D. only. In contrast, results showed that there is an increase in daily F.I. for the negative group (non-hepatotoxic) which fed on B.D. only as compared to positive group fed on B.D. only. The reduction in food intake for (+ve) group could be possibly explained by the toxic effect of $\mathrm{CcL}_{4}$. In this respect Cokamoto et al., (2001) suggested that 
the oral administration of a low dose of carbon tetrachloride to rats reduced food intake at $24 \mathrm{~h}$ with a minimal effect on plasma alanine aminotransferase activity.

Our results revealed that diet supplemented with 6 or $9 \%$, P.G.L.L. showed significantly increased F.I. and B.W.G.\% as compared to the other positive groups fed on B.D only.

Concerning liver weight/body weight\% results showed that hepatotoxic groups which fed on B.D. only (positive control and hepatotoxic groups which treated with different levels of P.G.L. leaves showed significant decrease in the relative weight of the liver as compared to the control (+ve) group. The best results recorded by group which fed on B.D. supplemented with P.G.L. leaves at level 9\%.

In this concern (Boyd-Kimball et al., 2005) reported that polyphenolic compounds that are widely distributed in fruits and vegetables exhibit a wide variety of health protective properties such as free radical scavenging, metal chelation.

\section{Effect of Psidium Guajava L. Leaves on Lipid Fractions:}

Effect of P.G.L.L. on serum total cholesterol (TC) triglycerides (TG) , high density lipoprotein cholesterol (HDL-c), Low density lipoprotein cholesterol (LDL-C) and very low density lipoprotein cholesterol (VLDL-C) in hepatotoxic rats are presented in table (5), results revealed that the values of serum $(T C)$ and $(T G)$ significantly increased $(P<0.05)$ for positive control (hepatotoxic group), as compared to negative control group. Concerning the mean value of serum HDL-c it could be noticed that the positive control group exhibited a markedly significant decrease as compared to the negative control group. These actions may be related to the action of $\mathrm{CCL}_{4}$.

Carbon tetracholoride is a highly toxic chemical again. The toxic effects of CCL4 on liver have been known for several years which cause an increase oxidative state (Dianzani, 1991).

Our results revealed that, addition of P.G.L.L. $(3,6$ and $9 \% 0$ to the B.D. resulted in a significant $(P<0.05)$ reduction in the mean values of serum (TC, TG, LDL-c and VLDL-c) as compared to the (+ve) control group. On the other side, all treated groups with different levels of P.G.L.L. showed significantly increased $(P<0.05)$ in the level of serum HDL-C, as compared to the positive control group which fed only on the B.D.

In this respect, El-Demerdash et al., (2005) cleared that, abnormally high levels of free radicals and the stimulation decline of antioxidant defense mechanism may lead to the damage of cellular organelles and enzymes, increased lipid peroxidation, free radicals generated in-vivo, including reactive oxygen species, are responsible for the oxidative damage to lipid, protein, deoxyribonucleic acid (DNA) and small molecules (Ajila and Prasada, 2008).

Our results indicated that P.G.L.L. contained high level of total phenolic compounds. The potent antioxidant activity of phynolic compounds may be related to its action as scavenger and inhibitors of lipid peroxidation (Karaca et al., 2006). 


\section{Effect of Psidium Guajava L., Leaves on Liver Enzymes in Hepatotoxic} Rats:

Results in table (6) illustrate the effect of P.G.L.L. on the levels of serum aspartate aminotransferase (AST), alanine aminotransferase (ALT). Results revealed that, the levels of AST and ALT increased significantly in the positive control group which fed only on B.D., as compared to the negative control group. In this respect Sallie et al., (1991) demonstrated that the rise in levels of serum AST and ALT has been attributed to the damaged structural integrity of the liver, because these enzymes are cytoplasmic in location and released into circulation after cellular damages.

Feeding hepatotoxic rats B.D. supplemented with P.G.L.L. at levels (3, 6 and $8 \%)$ lead to a significant decrease $(P<0.05)$ in the levels of AST and ALT as compared to the positive control group. The best decrease in serum level of AST and ALT were recorded by hepatotoxic group which fed on B.D. supplemented with $9 \%$ Psidium Guajava L. Leaves.

In this concern Roy et al., (2006) indicated that Guava leaves extract was found to possess helpatoprotective activities.

In conclusion, Psidium Guajava leaves contain considerable number and high amount of healthy compounds namely polyphenols and flavonoids, which act as antioxidant, that can be of help for treatment of hepatotoxic and disturbed lipid pattern, further studies are needed to fortification of some staple foods with Psidium Guajava L., leaves, should be taken in to consideration to produce a protective high nutritive value food for hepatotoxic patients.

Table (1): Chemical Composition of (Psidium Guajava, L.) Leaves (\%).

\begin{tabular}{|l|l|l|l|l|l|}
\hline $\mathbf{g} / \mathbf{1 0 0} \mathbf{g}$ & Psh & Protein & Fiber & Carbohydrate & Fat \\
\hline Moisture & Ash & \multicolumn{1}{|l|}{$\mid$} \\
\hline 80,00 & 1.22 & 0.94 & 3.14 & 14.39 & 0.32 \\
\hline \hline $\mathbf{~ m g / 1 0 0 g}$ \\
\hline Ascorbic acid & Calcium & Phosphorus & Iron \\
\hline 247.01 & 30.49 & 34.00 & 1.10 \\
\hline
\end{tabular}

Table (2):Determination of Polyphenols and Flavonoids Compunds of dried Psidium Guajava L./, Leaves.

\begin{tabular}{|l|c|c|}
\hline Psidium Guajava L., & $\begin{array}{c}\text { Total polyphenol } \\
\mathbf{m g} / \mathbf{1 0 0 g}\end{array}$ & $\begin{array}{c}\text { Flavonoids } \\
\mathbf{m g} / \mathbf{1 0 0 g}\end{array}$ \\
\hline Leaves & 576.11 & 35.00 \\
\hline
\end{tabular}

Table (3): Identified Phenolic Compounds found in Dried Psidium Guajava L., Leaves.

\begin{tabular}{|l|c|}
\hline \% of Identified Compound per $\boldsymbol{\mu g} / \mathbf{1 0 0} \mathbf{m g}$ & $\begin{array}{c}\text { Psidium Guajava Leaves } \\
\text { Samples }\end{array}$ \\
\hline Gallic acid & 33.00 \\
\hline Progallic & 7.00 \\
\hline Catechin & 17.01 \\
\hline Protochatchioc & 30.18 \\
\hline Furan & 3.04 \\
\hline Ferulic acid & 27.35 \\
\hline Quercetin & 26.22 \\
\hline
\end{tabular}


Table (4): Biological Effect of Psidium Guajava L. Leaves on Daily food Intake, Body Weight Gain \% and Liver Weight/body weight $\%$ in hepatotoxic rats:

\begin{tabular}{|l|c|c|c|}
\hline \multicolumn{1}{|c|}{ Parameters } & $\begin{array}{c}\text { Food Intake } \\
\text { g/day/rat }\end{array}$ & $\begin{array}{c}\text { Body Weight } \\
\text { Gain } \%\end{array}$ & $\begin{array}{c}\text { Liver } \\
\text { Weight/body } \\
\text { Weight } \%\end{array}$ \\
\hline Control (-ve) & $14.300 \pm 1.563^{\mathrm{a}}$ & $51.938 \pm 4.796^{\mathrm{a}}$ & $2.751 \pm 0.120^{\dagger}$ \\
\hline Control (+ve) & $12.100 \pm 1.140^{\mathrm{cde}}$ & $-37.418 \pm 5.855^{\dagger}$ & $3.754 \pm 0.077^{\mathrm{a}}$ \\
\hline $\begin{array}{c}3 \% \text { of Psidium } \\
\text { Guajava L. Leaves }\end{array}$ & $12.500 \pm 1.275^{\mathrm{bcde}}$ & $-27.225 \pm 3.458^{\mathrm{e}}$ & $3.627 \pm 0.087^{\mathrm{ab}}$ \\
\hline $\begin{array}{c}6 \% \text { of Psidium } \\
\text { Guajava L. Leaves }\end{array}$ & $13.157 \pm 1.086^{\mathrm{ad}}$ & $7.352 \pm 1.017^{\mathrm{bc}}$ & $3.118 \pm 0.083^{\mathrm{d}}$ \\
\hline $\begin{array}{c}9 \% \text { of Psidium } \\
\text { Guajava L. Leaves }\end{array}$ & $13.300 \pm 0.791^{\mathrm{ac}}$ & $9.422 \pm 2.469^{\mathrm{b}}$ & $2.925 \pm 0.156^{\mathrm{e}}$ \\
\hline
\end{tabular}

Values are expressed as mean \pm S.D. $n=6$ rats.

Significant at $P<0.05$ using one way ANOVA test values which have different letters differ significantly, while those which have similar or partially are non-significant.

Table (5): $\quad$ Effect of Psidium Guajava L., Leaves on Lipid Fractions:

\begin{tabular}{|c|c|c|c|c|c|c|}
\hline \multirow{2}{*}{\multicolumn{2}{|c|}{ Groups $\quad$ Parameters }} & \multicolumn{5}{|c|}{ mg/dl } \\
\hline & & TC & TG & HDL-C & LDL-c & VLDL-C \\
\hline \multicolumn{2}{|c|}{ Control (-ve) basal diet (B.D) } & $\begin{array}{l}87.220^{9} \\
+5.019\end{array}$ & $\begin{array}{l}48.255^{\dagger} \\
+6.633\end{array}$ & $\begin{array}{l}52.400^{\mathrm{a}} \\
+1.701\end{array}$ & $\begin{array}{l}24.110^{9} \\
+2.903\end{array}$ & $9.650^{\dagger}$ \\
\hline \multicolumn{2}{|c|}{ Control (+ve) basal (B.D) } & $\begin{array}{r}206.046^{a} \\
+12.008\end{array}$ & $\begin{array}{r}144.542^{\mathrm{a}} \\
+12.625\end{array}$ & $\begin{array}{r}27.590^{\mathrm{e}} \\
+4.036\end{array}$ & $\begin{array}{c}149.347^{\mathrm{a}} \\
+5.851\end{array}$ & $\begin{array}{l}28.909^{\mathrm{a}} \\
+2.523\end{array}$ \\
\hline $\begin{array}{l}\text { 음 } \\
\text { 음 }\end{array}$ & $\begin{array}{l}\text { B.D. supplemented } \\
\text { with } 3 \% \text { of Psidium } \\
\text { Guajava L. Leaves }\end{array}$ & $\begin{array}{c}162.347^{b} \\
\pm 4.400\end{array}$ & $\begin{array}{c}122.222^{b} \\
\pm 4.660\end{array}$ & $\begin{array}{l}28.122^{\mathrm{de}} \\
\pm 2.731\end{array}$ & $\begin{array}{c}108.732^{b} \\
\pm 3.029\end{array}$ & $24.466^{b}$ \\
\hline$\stackrel{\Phi}{ \pm}$ & $\begin{array}{l}\text { B.D. supplemented } \\
\text { with } 6 \% \text { of Psidium } \\
\text { Guajava L. Leaves }\end{array}$ & $\begin{array}{c}130.292^{d} \\
\pm 9.120\end{array}$ & $\begin{array}{l}70.060^{\mathrm{e}} \\
\pm 6.491\end{array}$ & $\begin{array}{l}42.654^{\mathrm{b}} \\
\pm 3.750\end{array}$ & $\begin{array}{l}79.622^{d} \\
\pm 4.333\end{array}$ & $\begin{array}{l}14.014^{\mathrm{e}} \\
\pm 1.291\end{array}$ \\
\hline 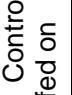 & $\begin{array}{l}\text { B.D. supplemented } \\
\text { with } 9 \% \text { of Psidium } \\
\text { Guajava L. Leaves }\end{array}$ & $\begin{array}{c}108.314^{\dagger} \\
\pm 6.574\end{array}$ & $\begin{array}{l}72.720^{\mathrm{e}} \\
\pm 6.444\end{array}$ & $\begin{array}{l}48.851^{\mathrm{a}} \\
\pm 5.981\end{array}$ & $\begin{array}{l}44.881^{\dagger} \\
\pm 1.342\end{array}$ & $\begin{array}{l}14.566^{\mathrm{e}} \\
\pm 1.285\end{array}$ \\
\hline
\end{tabular}

Values are expressed as mean \pm S.D. $n=6$ rats. Significant at $P<0.05$ using one way ANOVA test values which have different letters differ significantly, while those which have similar or partially are non-significant.

Table (6): Effect of Different Levels of Psidium Guajava L., Leaves on Liver Enzymes in Hepatotoxic Rats:

\begin{tabular}{|c|c|c|c|}
\hline \multirow{2}{*}{\multicolumn{2}{|c|}{$\begin{array}{ll}\text { Groups } & \text { Parameters } \\
\end{array}$}} & \multicolumn{2}{|c|}{ IU / I } \\
\hline & & AST & ALT \\
\hline \multicolumn{2}{|c|}{ Control (-ve) basal diet (B.D) } & $77.770+5.311^{\mathrm{g}}$ & $44.933+1.167^{\dagger}$ \\
\hline \multicolumn{2}{|c|}{ Control (+ve) basal (B.D) } & $180.221+12.725^{\mathrm{a}}$ & $120.225 \pm 8.880^{\mathrm{a}}$ \\
\hline \multirow{3}{*}{ 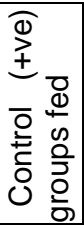 } & $\begin{array}{l}\text { B.D. supplemented with } 3 \% \text { of } \\
\text { Psidium Guajava L. Leaves }\end{array}$ & $161.581 \pm 3.410^{C}$ & $111.583 \pm 1.657^{b}$ \\
\hline & $\begin{array}{l}\text { B.D. supplemented with } 6 \% \text { of } \\
\text { Psidium Guajava L. Leaves }\end{array}$ & $130.211 \pm 5.666^{\mathrm{e}}$ & $88.916 \pm 3.910^{d}$ \\
\hline & $\begin{array}{l}\text { B.D. supplemented with } 9 \% \text { of } \\
\text { Psidium Guajava L. Leaves }\end{array}$ & $122.971 \pm 4.122^{\top}$ & $74.932 \pm 3.651^{\mathrm{e}}$ \\
\hline
\end{tabular}

Values are expressed as mean \pm S.D. $n=6$ rats.

Significant at $\mathrm{P}<0.05$ using one way ANOVA test values which have different letters differ significantly, while those which have similar or partially are non-significant.

AST. Aspartate Amino Transferase.

ALT. Alanine Amino Transferase. 


\section{REFERENCES}

(A.O.A.C.) Association of official Analytical Chemists (1995): Official method of Analytical Chemistry. Washington, D.C.

Ajila, C.M. and Prasada, U.J.S. (2008): Protection against hydrogen peroxide induced oxidative damage in rats erythrocytes by mangifera indieal peel extract. Food and Chemical Toxicology, 46: 303-309.

Allain, C.Z.; Poon, L.S. and Chan, C.S. (1974): Enzymatic determination of total serum cholesterol. Clin. Chem., 20: 470-475.

Amin, A. and Ghoneim, M.D. (2009): Zizyphus spina-christi protects against carbon tetrachloride-induced liver fibrosis in rats. Food and Chemical Toxicology, 47: 2111-2119.

Ben-Hammouda, M.; Kremer, R.J.; Minor, H.C. and Sarwar, M. (1995): A Chemical basis for differential allelopathic potential of sorghum hybrids on wheat. J. Chem. Ecol.; 21: 775-786.

Boyd-Kimball, D.; Sultana, R.; Poon, H.F.; Mohammed, A.H.; Lynn, B.C.; Klein, J.B. and Butterfield, D.A. (2005): Gamma-glutamyl cystein ethyl ester protection of proteins from Abeta (1-42). Mediated oxidative stress in neuronal cell cultre: a protecomics approach. J. Neuro Sci. Res.; 79; 707-13.

Campbell, J.A. (1963): Methodology of protein evaluation, RAG, nutrition Doc. R. 10/Led 37, June Meeting New York.

Caporale, G.A.; Bettaro, A. and Innocenti, C. (1985): Determination of the coumarinic constituents of ficus carica leaves by HPLC. Farmaco. J. Sch. 37 (7): 475-85.

Chapman, D.G.; Castilla, R. and Cambell, A.J. (1959): Evaluation of protein in food. In Method for the Documentation of protein Efficiency Ratio. Can. J. Biochem. Physiol., 37; 679-686.

Chen, H.Y. and Hen, G.C. (2007): Antioxidant activity and free radical scavenging capacity of extracts from guava (Psidium Guava, L.) Leaves. Food Chemistry, 104: 1418-1424.

Chuanoi, S.; Weerataweepornls, S.D.; Mangit, C.; Pitiporn, S. and Kamkenl, N.C. (2009): Development of guava liposome serum and evaluation of free radical scavenging capacity J. Health Res; 23 (4): 163-167.

Cokamoto, T.; Masuda, Y.; Kawasaki, T. and Okabe, S. (2001): Zaltoprofen prevents carbon tetrachloride induced reduction of body weight in rats. Int. J. Mol. Med., 101:4.

Dianzani, M.U. (1991): Biochemical aspects of fatty liver. Hepatotoxicology, CRC Press, Boca Raton, F., 327-399.

El-Demerdash, F.M.; Yousef, M.I. and Abou El-Naga, N.I. (2005): Biochemical Study on the hypoglycemic effects of onion and garlic in alloxan-induced diabetic rats. Food and Chemical Toxicology,43:57-63.

Friedwald, W.T.; Leve, R.J. and Fredrickson, D.S. (1972): Estimation of the concentration of low-density lipoprotein separation by three different method. Clin. Chem., 18; 499-502. 
Gutierrez, P.M.R.; Mitchell, S. and Solis, V.R. (2008): Psidium Guajava, L. traditional uses. Photochemical and Pharmacology. J. of Entho Pharmacology, 117: 1-27.

Han, X.; Shen, T. and Lou, H. (2007): Dietary Polyphenols and their biological significance. Int. J. Mol. Sci., 8: 950-988.

Hegsted, D.M.; Mills, R.C.; Elvehjem, C.A.; Hart, E.B. Henry, J.B.; Todd, M.K.; Sanford, L.U. and Davidsohn, S.G. (1941): Clinical diagnosis and measurement by laboratory methods. $16^{\text {th }}$ ed., Saunders and Co., Philadelphia, P.A. 260.

Karaca, T.; Cemek, M. and Kanter, M. (2006): Lipid Peroxidation and antioxidant level and alphanaphthyl acetate esterase activity blood lymphocytes in mallard Muscovy and Pekin Ducks. Acta Vert Bron, 75: 33-38.

Lee, C.H.; Park, S.W.; Kim, Y.S.; Kang, S.S.; Kim, J.A.; Lee, S.H.; and Lee, S.M. (2007): Protective mechanism of glycyrrhizin on acute liver injury induced by carbon tetrachloride in mice. Biological \& Pharmaceutical Bulletin, 30: 1898-1904.

Lopes-Vitelia; M.F.; Stone, S.S.; Ellis, S. and Collewellm, J.A. (1977): Cholesterol determination in high density lipoproteins separated by three different methods. Clin. Chem., 23 (5): 882-893.

Mumoli, N.; Cei, M. and Cosimi, A. (2006): Drug-related hepatotoxicity. N. Engl. J. Med., 354 (20): 2191-3.

Nooman, Z.M.; Khalil, M. and Nofeh, M. (1997): Behaviour of hepatitis bantigen in bilharzias patients infected with HBS positive viral hepatitis. E.g.J. Billh, 4: 79.

Oh, K.W.; Lee, H.C.; Lee, S.M.; Bac, Y.E.; Sohan, B.C.; Oh, H.; Kim, Y.B. and Ahn. S.Y. (2004): Antidiabetic effects of extracts from Psidium Guajava, L.J. of Ethnopharmacology, 96: 411-415.

Price, M.L.; Vah-Scouo, C.S. and Buttet, L.G. (1978): A critical evaluation of the vanillin reaction as an assay for tannins sorghum green J. Agric. Food Chem., 26: 5.

Reeves, P.G.; Hielsen, F.H. and Fahmy, G.G. (1993): Reported of the American Institute of Nitrition Adhoc Wiling Committee on the Reformulation of the AIN-76A rodent Diet. J. Nutr.; 123: 1939-1951.

Ritman, S. and Frankel, S. (1957): Determination of glutamate pyruvate transferase. Am. J. Clin. Path., 28-56.

Ronda Behnke, N.D. and Chom, P.R.N. (2007): Liver Toxicity, $10^{\text {th }}$ ed, New York, pp. $42-47$.

Roy, C.K.; Kamath, J.V. and Asad, M. (2006): Hepatoprotective activity of Psidium Guajava L. Leaf extract. Indian. J. Exp. Biol., 44(4): 305-311.

Sallie, R.; Tredger, J.M. and William, R. (1991): Drugs and liver. Part I. Testing liver function Biopharm. Drug. Disp., 12: 251-259.

SAS. (2004): Statistical analysis system. SAS user Guide: Statistics. SAS Institute Inc. Editors, Cary, NC.

Schermer, S. (1967): The blood morphology of laboratory animal Longmans, Printed in Great Britain, Green and Co., LTD 350. 
Shen, X.; Tang, Y.; Yang, R.; Yu, L.; Fang, T. and Duan, J. (2009): The protective effect of zizy Phus jujube fruit on carbon tetrachlorideinduced hepatic injury in mice by anti-oxidative activities. J. of Ethnopharmacology, 122: 555-560.

Trinder, P. and Ann, S. (1969): Enzymatic colorimetric test with lipid clearing factor to determine triglyceride. Clin. Biochem., 6: 24-27.

\section{تأثير أوراق الجوافة كمصدر لمضادات الأكسدة على الفئران المصابة بتشمم الكبد

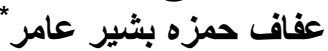 *قسم علوم الأغذية , كلية علوم الأسرة ، جامعة طيبة، المملكة العربية السعودية.}

أجريت هذه الدراسة لمعرفة تأتثير إضـافة تركيز ات مختلفة من مجفف ومطحون أوراق

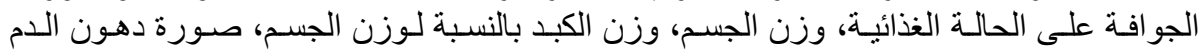
ووظائف الكبد في الفئران المصابة بتسمم الكبد. وقد تم استخدام ثلاثثون فأر من فئر ان ان الألبينو الذكور

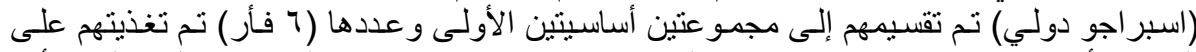

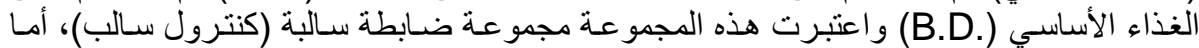

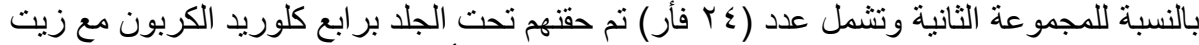

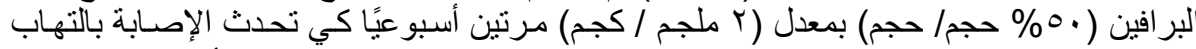

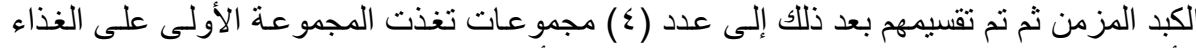

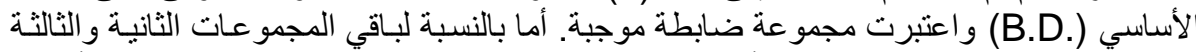

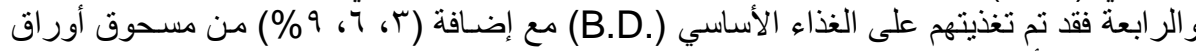

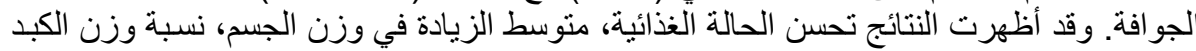

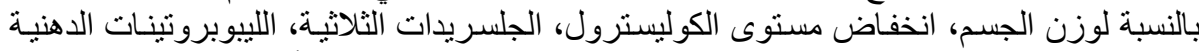

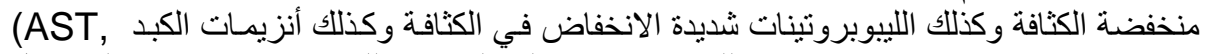

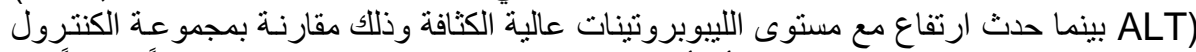

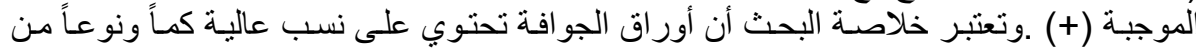

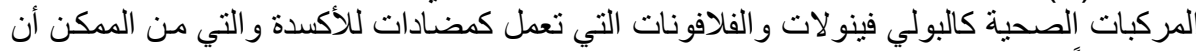

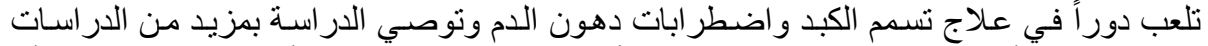

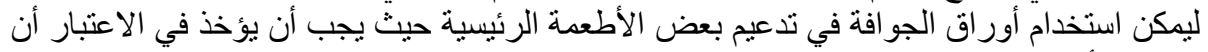

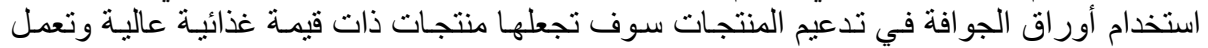

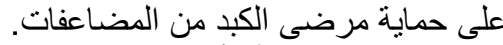

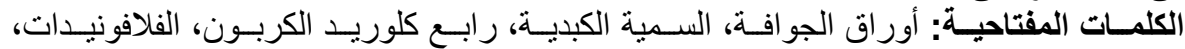
الكوليسترول، الجلسريدات الثلاثية. 